\title{
Sharia Insurance Company Business Management Model in The Digital 4.0 Era
}

\author{
Renny Oktavia1, M. Taufiq ${ }^{2}$ \\ 1),2) Program Studi Ekonomi Pembangunan, Universitas Pembangunan Veteran Jawa Timur, Indonesia \\ Email: renny.oktafia.es.@upnjatim.ac.id
}

\begin{abstract}
:
This study aims to determine how the business management model of Islamic insurance companies in the digital era 4.0. The research method used is a qualitative research method using the Grounded Theory approach. The results of this study explain that, in running the insurance business in the era of revolution 4.0 implementing a supporting system, it is a combination of four components, namely: insurance / financial literacy, network marketing, human technology, and digital technology. The four components are driven by three mechanisms, namely: digital funneling, learning models, gamification systems, to achieve targeted business results.
\end{abstract}

Keywords: Insurance Business, Sharia Insurance, Digital Technology

\begin{abstract}
Abstrak:
Penelitian ini bertujuan untuk mengetahui bagaimana model manajemen bisnis perusahaan asuransi syariah di era digital 4.0. Metode penelitian yang digunakan adalah metode penelitian kualitatif dengan menggunakan pendekatan Grounded Theory. Hasil penelitian ini menjelaskan bahwa dalam menjalankan bisnis asuransi di era revolusi 4.0 menerapkan sistem pendukung yang merupakan gabungan dari empat komponen yaitu: asuransi/literasi keuangan, network marketing, human technology, dan digital technology. Keempat komponen tersebut didorong oleh tiga mekanisme, yaitu: digital funneling, model pembelajaran, sistem gamification, untuk mencapai hasil bisnis yang ditargetkan.
\end{abstract}

Kata Kunci: Bisnis Asuransi, Asuransi Syariah, Teknologi Digital 


\section{INTRODUCTION}

In the business world, one of the sectors that is an important partner in developing a business is the financial sector. The financial industry is currently growing rapidly, including the Islamic finance industry. The Islamic finance industry is experiencing encouraging growth, not only in Muslim-majority countries, but also in non-Muslim countries. This is also experienced by one of the non-bank Islamic finance industry, namely sharia insurance.

In Indonesia, sharia insurance companies generally experience fluctuating growth. This is indicated by the steady growth in the number of sharia insurance players in 2018 and 2019, which were 13 full fledge units and 49 sharia business units. However, in 2020 and 2021 there will continue to be a slight decline in sharia business units, which are 47 units in 2020 and 46 units in 2021, respectively, while the full fledge unit is still stable at 13 units ${ }^{1}$. These conditions, can be described as in Figure 1 below.

Figure 1.Number of Sharia Insurance Players in 2018 - 2021

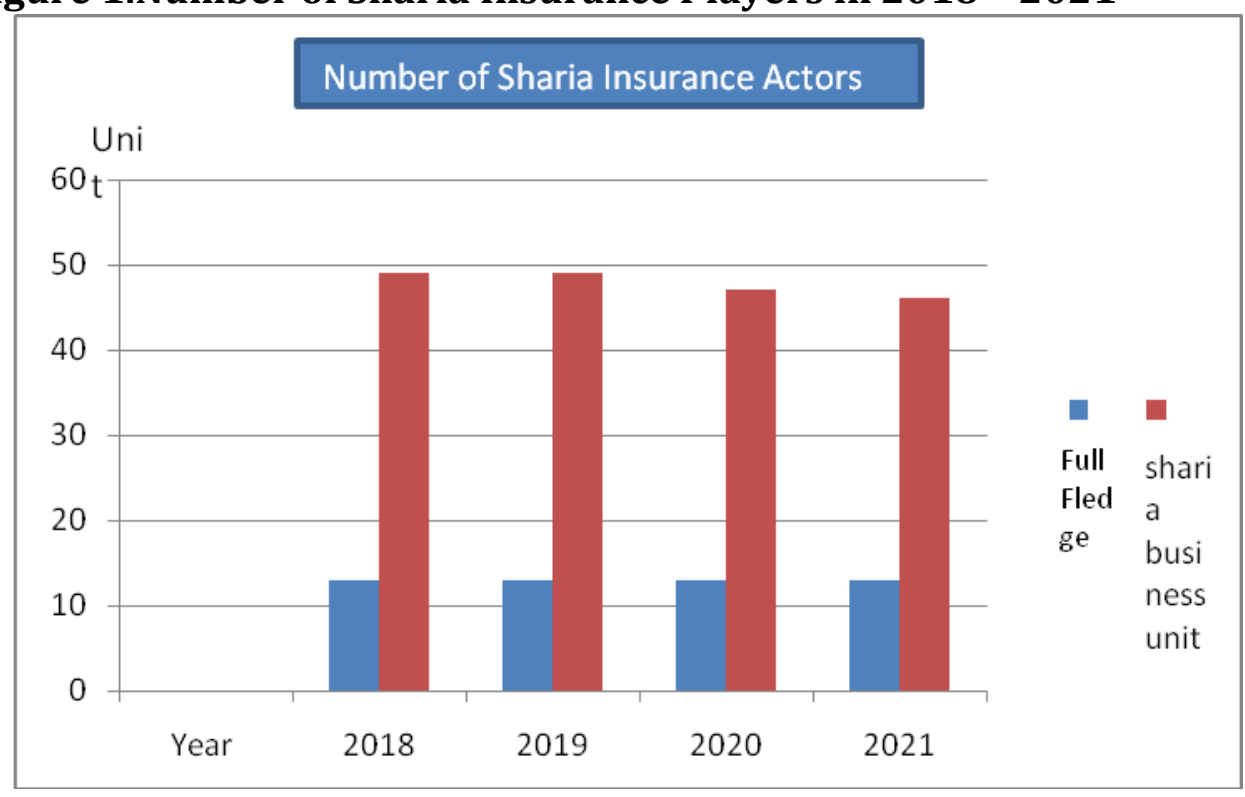

Source: Secondary data processed from www.ojk.go.id

In addition, in terms of growth in assets of sharia insurance companies, it also shows fluctuating developments from 2018 to 2021. In 2018, the total assets of Islamic insurance companies stood at 41,915 billion. Then, in 2019 there was a significant increase to 45,795 billion. However, in 2020 and 2021, respectively, experienced a decrease of 44,440 billion and 44,136 billion, respectively. The data, can be shown as in Figure 2 below.

\footnotetext{
${ }^{1}$ www.ojk.go.id,"Statistik-IKNB-Syariah-Periode-Maret-2021,” Https://Www.Ojk.Go.Id/Id/Kanal/Syariah/Data-Dan-Statistik/Iknb-Syariah/Pages/Statistik-IKNBSyariah-Periode-Maret-2021.Aspx, Accessed Mei 27, 2021.
} 
Figure 2.Total Assets of Sharia Insurance Companies in 2018 - 2021

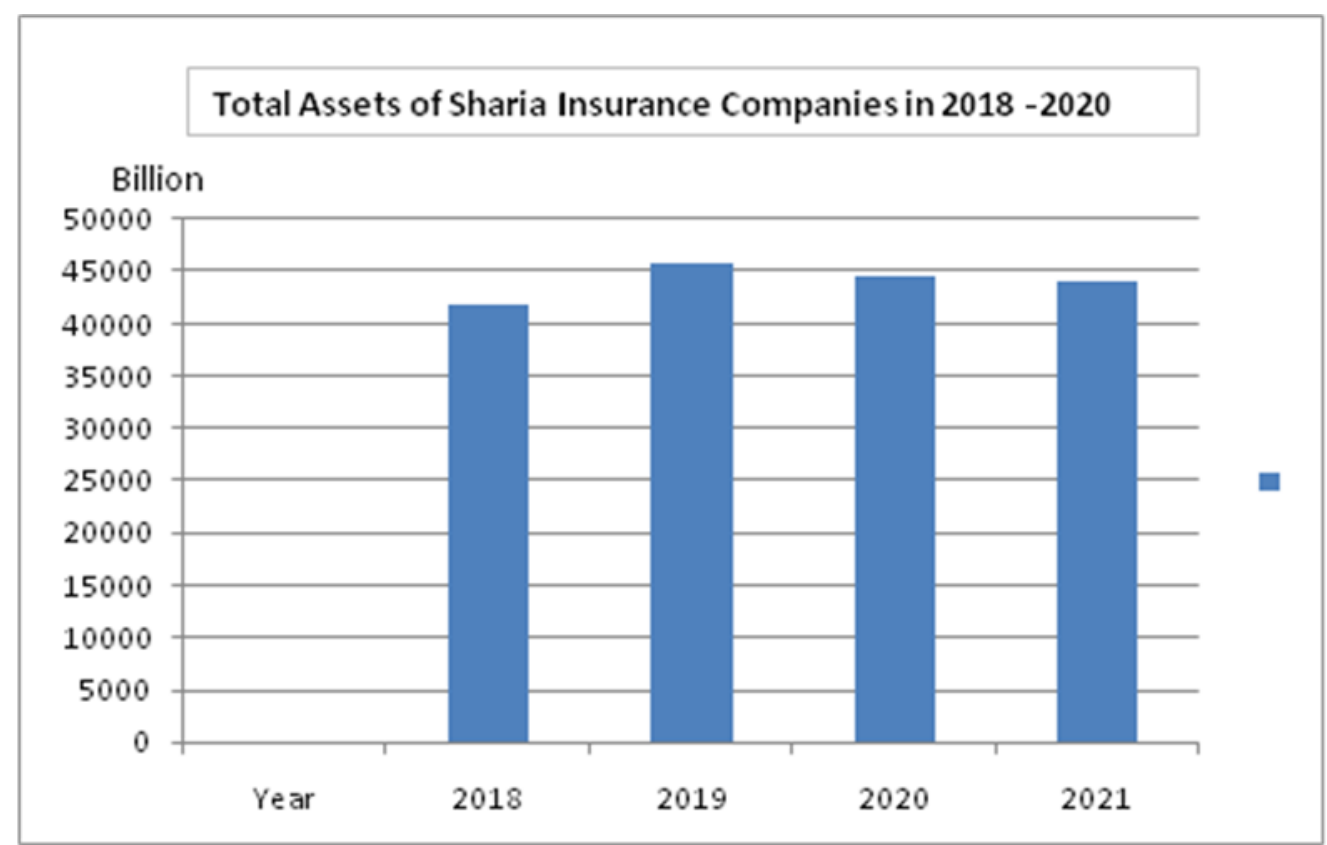

\section{Source: Secondary data processed from www.ojk.go.id}

The fluctuating growth conditions of insurance companies, such as the explanation of ditas, can be caused partly by the prospects and challenges faced by Islamic insurance companies in Indonesia. This is as research conducted by Herry Ramadhani, which discusses that basically the growth of sharia insurance has very good prospects, because it is supported by the population of Indonesia, which is predominantly Muslim. However, it also has to face quite formidable challenges, during the global economic downturn, public understanding of sharia insurance is still low, and the lack of resources that have the capacity in the field of sharia insurance. This, in turn, can lead to a decline in the growth of Islamic insurance in Indonesia ${ }^{2}$.

Another research that shows the opportunities and challenges in managing sharia insurance companies has been carried out by Nurul Ichsan. In his research, he explained that the factors that became a challenge for Islamic insurance companies were external factors. This is related to the ability of Islamic insurance companies to find product innovations that match market demand. In this way, internal strength is required to come up with innovative products and services based on the basic concept of sharia, so as to increase the penetration of the sharia insurance market ${ }^{3}$.

Based on the description above, it shows that the growth of insurance companies in Indonesia still needs to be encouraged. The main reason for continuing to drive the growth of the insurance market is the low level of insurance penetration in Indonesia. This condition

2 Herry Ramadhani, "PROSPEK DAN TANTANGAN PERKEMBANGAN ASURANSI SYARIAH DI INDONESIA Herry," AL-TIJARY Vol. 01, no. No. 01 (n.d.): 57-66.

${ }^{3}$ Nurul Ichsan, "Peluang Dan Tantangan Inovasi Produk Asuransi Umum Syariah," Jurnal Ekonomi Islam 7, no. 2 (2016): 131-156. 
Sharia Insurance Company Business Management Model in The Digital 4.0 Era can be seen from the insurance penetration rate which is still at $2.8 \%$. This penetration rate is a number that shows the insurance company's premium income divided by the Gross Domestic Product (GDP) figure. The insurance penetration rate in Indonesia is very small when compared to other countries such as Singapore which reached 7\%, the United States $7.1 \%$ and the UK $12.2 \% 4$.

Thus, we need a management model that can be used by Islamic insurance companies, in managing their business and can increase the level of penetration of the sharia insurance market. This sharia insurance company management model, of course, must be adjusted to the conditions of the times and technology, which are also important in running the business of a sharia insurance company. Therefore, in this study, the formulation of the problem is how the business management model of sharia insurance companies is in the digital 4.0 era.

\section{LITERATURE REVIEW}

\section{Sharia Insurance Industry in Indonesia}

In Indonesia, sharia insurance can be used as a way for the Indonesian Muslim community to lock in the risk of life in the future. With sharia insurance, it is expected to minimize the risks that will be faced and avoid a bigger financial disaster. However, the concept of thinking as described above, cannot be understood and accepted by the community. The contributing factor is the public perception of sharia insurance is still very lacking, so efforts are needed from sharia insurance companies to be wider in socializing sharia insurance to the public 5 .

In addition, the performance of Islamic insurance can support the perception that is formed in the community, in 2012-2019 the profit of Islamic life insurance companies in Indonesia is influenced by contribution income, investment returns, and claim costs ${ }^{6}$. The financial performance of sharia general insurance companies in Indonesia is also influenced by several indicators, namely company size, company age, capital volume growth and investment growth ${ }^{7}$.

The development of sharia insurance in Indonesia itself can be said to be still lagging behind neighboring Malaysia. One of the reasons is related to the regulations formed in response to the needs of the Indonesian people for sharia insurance, which are still less responsive. This is because in Indonesia the law only acts as a tool of social control, in responding to the rapid changes in sharia insurance in accordance with the changing times. This condition is a factor in the development of the sharia insurance industry in Indonesia, which is slower than Malaysia8.

\footnotetext{
${ }^{4}$ www.jiwasraya.co.id,"Adu-Inovasi-Produk-Di-Kancah-Pertarungan-Asuransi-Jiwa," Https://Www.Jiwasraya.Co.Id/?Q=id/Berita/Berita-Asuransi/Adu-Inovasi-Produk-Di-KancahPertarungan-Asuransi-Jiwa, Accessed May 28, 2021.

5 Tati Handayani and Muhammad Anwar Fathoni, "Persepsi Masyarakat Terhadap Asuransi Syariah," Conference on Islamic Management Accounting and Economics 2 (2019): 127-132.

${ }^{6}$ Laila Mardiyah Nainggolan; Andri Soemitra, "The Contribution Income, Investment Results, and Claim Expenses on Sharia Life Insurance Income," JEBIS : Jurnal Ekonomi dan Bisnis Islam 6, no. 2 (2020): 201-220.

${ }^{7}$ Sofiyatul Munawaroh and Hasan Mukhibad, "Determinan Yang Mempengaruhi Financial Performance Pada Perusahaan Asuransi Umum Syariah Di Indonesia," IQTISHADIA: Jurnal Ekonomi \& Perbankan Syariah 6, no. 2 (2019): 155.

${ }^{8}$ Inneke Wahyu Agustin, "Perbandingan Pengembangan Asuransi Syariah Di Indonesia Dan Malaysia (Analisis Aliran Mazhab Sejarah Dan Law as a Tool of Social Engineering)," Al-Ahkam Jurnal Ilmu Syari'ah dan Hukum 5, no. 1 (2020): 37-57.
}

Iqtishadia: Jurnal Ekonomi dan Perbankan Syariah

Vol. 8 No. 2 Desember 2021 
In carrying out its business activities, sharia insurance is based on mutual cooperation, responsibility, guarantee, protection and assistance between groups of participants. This principle is what causes the growth of the Islamic insurance industry to increase by $30 \%-40 \%$ in 2013, based on data from Asosiasi Asuransi Syariah Indonesia (AASI). With the pattern owned by sharia insurance, which gives members the opportunity to benefit in two ways, namely the benefits of financial security with risk sharing arrangements and spiritual benefits, it is expected to encourage the prospect of the sharia insurance industry to grow bigger in Indonesia ${ }^{9}$.

The business activities of sharia insurance companies, on the internal side, must also consider the emergence of risk problems, which will certainly be faced by insurance companies, but the company can minimize the risks that arise. It aims to create efficiency and effectiveness to facilitate the achievement of company goals. The types of risks faced by insurance companies, among others: operational risks such as default, legal risk, and reputation risk. Another risk faced, caused by factors from internal and external to the company is the risk related to moral hazard ${ }^{10}$.

\section{Application of Akad in Sharia Insurance}

In sharia insurance, the contract is an important part as a basis for sincere intentions to provide benevolent funds in helping fellow Islamic insurance participants, if someone is affected by something between them. Therefore, the contract used is called the Tabarru 'contract, which is regulated in Fatwa Dewan Syariah Nasional No.53/DSN-MUI/III/2006 regarding sharia insurance. Tabbaru 'is a contract that must be attached to a sharia insurance agreement, because in Islamic insurance there is a premium amount that must be issued by the participant, as risk coverage which we do not know when it will happen ${ }^{11}$.

The risks faced in human life can be in the form of the risk of loss, the risk of accidents and even the risk of death. Therefore, it is necessary to prepare coverage for protection and fulfill the need for a sense of security. These needs can be obtained through sharia insurance, which is indeed made as an effort to protect and help a number of parties, if they experience certain risks with contracts in accordance with sharia. There are two contracts attached to sharia insurance, namely the Tijarah contract and the Tabarru contract. The contract that follows the Tijarah contract includes the mudharabah and musyarakah contracts. In addition, there are other contracts that follow in the practice of sharia insurance, namely the Wakalah bil Ujrah contract ${ }^{12}$.

\section{Sharia Insurance Strategy in Increasing the Number of Customers}

In Islamic insurance companies, the agent's ability to set strategies in increasing the number of customers is very important. Strategies that can be used by agents include: first, expanding the market through direct outreach to customers or prospective customers;

\footnotetext{
${ }^{9}$ Afif Effendi, "ASURANSI SYARIAH DI INDONESIA (Studi Tentang Peluang Ke Depan Industri Asuransi Syariah)," Wahana Akademika: Jurnal Studi Islam dan Sosial 3, no. 2 (2016): 71.

${ }^{10}$ Toyyibah Toyyibah and Erie Hariyanto, "Implementasi Manajemen Resiko Pada Sistem Asuransi Jiwa Syariah Di Pt. Prudential Life Assurance Cabang Madura," IQTISHADIA: Jurnal Ekonomi \& Perbankan Syariah 2, no. 2 (2015): 146.

${ }^{11}$ Aryani Witasari and Junaidi Abdullah, "Tabarru" Sebagai Akad Yang Melekat Pada Asuransi Syariah," BISNIS : Jurnal Bisnis dan Manajemen Islam 2, no. 1 (2014): 115.

${ }^{12}$ Junaidi Abdullah, "Akad-Akad Di Dalam Asuransi Syariah," TAWAZUN : Journal of Sharia Economic Law 1, no. 1 (2018): 11. 
Sharia Insurance Company Business Management Model in The Digital 4.0 Era secondly, maintaining and at the same time increasing the existing market by always maintaining communication with customers as part of providing the best service; third, introducing financial planning and risk management in Islamic insurance, selecting, measuring and evaluating the amount of risk that may occur to customers ${ }^{13}$.

Strategies to increase the number of customers in sharia insurance companies can also be done by applying the methods contained in the marketing strategy. The implementation of this marketing strategy, has been carried out by the Sharia Insurance AJB Bumiputera 1912 Curup, in increasing the number of customers. This sharia insurance company, applies the elements contained in the marketing strategy, namely product, place, price and promotion by means of personal selling and advertising. This marketing strategy has been able to increase the number of AJB Bumiputera 1912 Curup Sharia Insurance customers $^{14}$.

In addition, to increase market share and the existence of sharia insurance companies, the role of sharia insurance agents is very much needed in providing complete and detailed information about sharia insurance products, systems, uses, and benefits. For this reason, sharia insurance agents can more often carry out sharia insurance literacy activities to the entire community on an ongoing basis. This strategy, indeed requires sharia insurance agents to continue to upgrade their capabilities in mastering sharia insurance products and technology that is marketed, which continues to grow from time to time. Another important strategy is the existence of a legal basis specifically regulating sharia insurance, which policymakers in Indonesia need to issue immediately ${ }^{15}$.

\section{Technology in Insurance Premium Payment Transactions}

In the era of the industrial revolution 4.0, all aspects of life are required to run quickly, easily and safely. Therefore, technology is very necessary to respond to the demands of the development of the industrial era 4.0 which makes all sectors experience changes and shifts so quickly. Likewise with insurance companies, which need to meet customer needs in knowing information about policies and making insurance payments quickly, easily, comfortably and safely. Digital technology in the form of a customer service mobile application, can be a solution for agents and customers, so that the cycle of buying and paying for insurance can be simplified, in terms of processing time can be faster ${ }^{16}$.

\section{RESEARCH METHOD}

This study uses a type of qualitative research method using the Grounded Theory (GT) approach. The reason for choosing the Grounded Theory (GT) approach to reveal a phenomenon that can produce a theory that explains the phenomena related to the business

13 Muhammad Fahmul Iltiham and Dian Wahyuni, "STRATEGI AGEN ASURANSI SYARIAH DALAM MENINGKATKAN JUMLAH NASABAH (Studi Kasus Di PT. Asuransi Takaful Indonesia Malang)," Malia 7, no. 1 (2016): 1-26.

${ }^{14}$ Hendrianto and Riska Misdalepa, "STRATEGI MARKETING MENINGKATKAN NASABAH ASURANSI SYARIAH (STUDI KASUS DI ASURANSI SYARIAH AJB BUMIPUTERA1912 CURUP) Hendrianto," Al-Qasd 1, no. 2 (2017): 127-142.

${ }^{15}$ Dinna Miftakhul Jannah and Lucky Nugroho, "Strategi Meningkatkan Eksistensi Asuransi Syariah Di Indonesia," Jurnal Maneksi 8, no. 1 (2019): 169-176.

${ }^{16}$ Rahma Lili Erfida Sholiha Rafidah, "Pembayaran Premi Asuransi Melalui Aplikasi Mobile Agen Dalam Rangka Penguatan Bisnis Di Revolusi Industri 4.0 Di Jambi Indonesia," Al-Masraf (Jurnal Lembaga Keuangan dan Perbankan) 5, no. 1 (2020): 11-20. 
management model of Islamic insurance companies in the digital era 4.017. This research was conducted at the Sharia Business Unit of PT. Allianz Life Indonesia Insurance. The insurance company Allianz, is one of the largest insurance companies in the world, based on Forbes 2021 data which is summarized in the World's Largest Public Companies, Allianz is ranked 24 th as the largest company in the world ${ }^{18}$.

The types and sources of data in this study used primary data and secondary data, which were obtained from interviews with agents and business actors of allianz sharia, profile data of sharia business units of PT. Allianz Life Indonesia Insurance, sharia insurance books, and scientific journals with sharia insurance topics from previous research ${ }^{19}$.

Researchers used three techniques in data collection, namely the first observation by applying passive participation techniques because the researcher only observes and is not involved in these activities. Both interviews were conducted in depth by giving a question to the party to be interviewed. Third, documentation as supporting data in conducting research and can be recognized accurately ${ }^{20}$.

In this study, researchers used data analysis techniques with stages developed by Colaizzi, namely, first by describing the phenomenon being studied about the business management model of Islamic insurance companies in the digital era 4.0. the second collects descriptions from the informants regarding the phenomenon being studied. Third, make a transcript of the data from the answers of the informants who are being studied. The fourth provides an in-depth presentation of the results of the research description by validating the results of the analysis of data obtained directly to informants ${ }^{21}$.

\section{RESULT AND DISCUSSION}

\section{Changes in the Allianz Insurance Industry System}

Industrial changes in the world are always evolving following the course of the industrial revolution, which aims to make it easier for humans to carry out activities and fulfill their needs. The industrial revolution itself, up to now, has gone through four phases of change, namely: industrial phase 1.0, which refers to water steam: mechanization, steam power, weaving loom, and steamship; industrial phase 2.0, leads to electricity: mass production, assembly line, electrical energy; industrial phase 3.0, leading to automation: automation, computers, electronics; industrial phase 4.0, refers to cyber physical systems: internet of things, networks.

The insurance industry has also experienced a revolution, including Allianz insurance, which has undergone four revolutionary phases, namely: revolution 1.0, in this phase Allianz applies a branch system pattern, where the system in place is to recruit employees to develop its business; revolution 2.0, Allianz implements an agency system to market its products; revolution 3.0, in this phase Allianz in increasing sales applies a form of business system; and revolution 4.0, Allianz began to develop its business following the changes in industry 4.0

\footnotetext{
17 Steven J. Taylor Bogdan, Robert C, Prosedur Penelitian. Dalam Moleong, Pendekatan Kualitatif (Jakarta: Rineka Cipta, 2012).

${ }_{18}$ Www.forbes.com, "Lists Global2000," Https://Www.Forbes.Com/Lists/Global2000/\#295563545ac0. 2021, Accessed May 28, 2021.

${ }^{19}$ Moh. Nazir, Metode Penelitian (Bogor: Ghalia Indonesia, 2017).

20 Sugiyono, Metode Penelitian Kualitatif, Kuantitatif, Dan R\&D, Cet. Ke-27. (Bandung: ALFABETA, 2018).

${ }^{21}$ Ahmad Tanzeh, Metodologi Penelitian Praktis (Yogyakarta: Teras, 2011).

$228 \quad$ Iqtishadia: Jurnal Ekonomi dan Perbankan Syariah

Vol.8 No.2 Desember 2021
} 
Sharia Insurance Company Business Management Model in The Digital 4.0 Era which required the use of digital technology, thus implementing a supporting system. This explanation can be illustrated in Figure 3 below.

\section{Figure 3. The Allianz Insurance Industry Revolution}

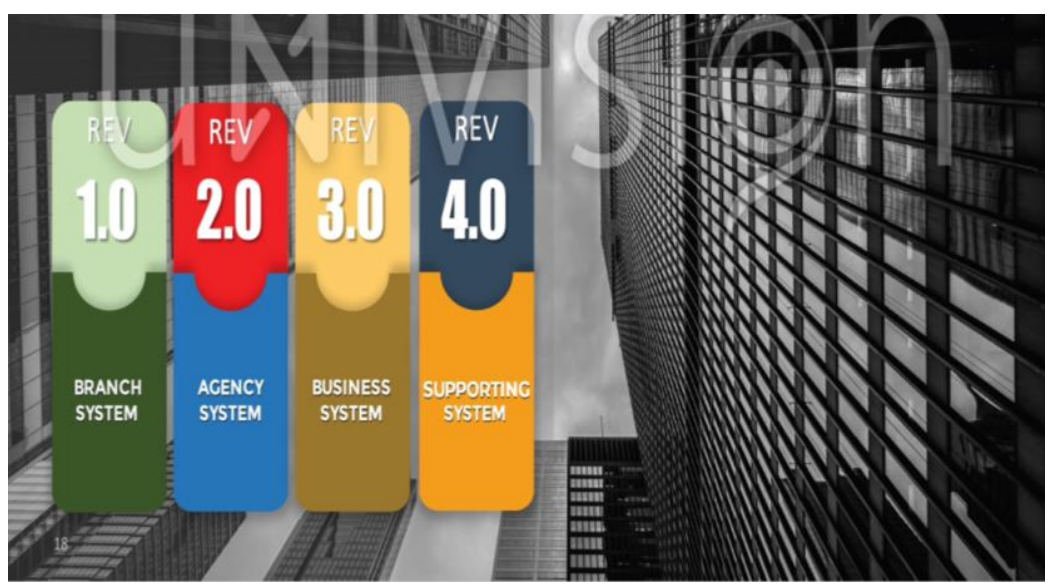

Source: Primary data processed

\section{Development of Allianz Syariah in Indonesia}

PT. Allianz Life Indonesia Insurance is an insurance company originating from Germany, founded in 1980, when it has operated on 6 continents and spread across 70 countries. In Indonesia, Allianz Insurance was entered in 1981 and in 2006 the Allianz Syariah Business Unit was established. The total number of Allianz Insurance customers worldwide is 86 million customers, and in Indonesia it has reached 7 million customers.

The legality of the operation of the Sharia Unit of PT. Asuransi Allianz Life Indonesia in 2006, based on the Decree of the Minister of Finance No : KEP-440/KM.5/2005 regarding the granting of a license to open a branch office with sharia principles on December 20, 2005. In addition, it is also based on Recommendations of Dewan Syariah Nasional - Majelis Ulama Indonesia (DSN-MUI) No : U-132/DSN-MUI/VII/2005 regarding the Recommendation for the Determination of the Sharia Supervisory Board. The contract used by Allianz Syariah in carrying out its operational activities is the Tabbaru contract in the form of the Ta'awun contract, where each participant is willing to help each other in case of risk, and the Tijarah contract, which is related to business orientation.

The Allianz Syariah Business Unit is also getting a positive response from the public, therefore to support market partners in carrying out business activities and providing excellent service to the community, on March 4, 2020, Allianz Indonesia inaugurated the Allianz Sharia Business Lounge. This is intended to be utilized by marketers in carrying out various activities ranging from customer meetings, discussion of business concepts to training and development of sharia business. With the presence of the Allianz Sharia Business Lounge, it is hoped that it can increase public awareness of the concept of goodness that exists in Sharia Insurance.

The Sharia Insurance strategy in increasing the number of customers is very much needed, where currently $70 \%$ of the total insurance customers are obtained from the agent's marketing channels directly, not from advertising. Therefore, the role of the Indonesian Life Insurance Association and insurance companies to provide the best education to agents, can greatly affect the increase in the number of customers. The current trend, agents are 
encouraged to understand the contents of the contract contained in the insurance policy well. Crucial things that also need to be understood are the rights and obligations of customers to insurance companies, the process of submitting claims, the amount of fees charged, as well as exceptions. If this can be carried out properly, it will increase the trust of prospective customers.

\section{Allianz Syariah Business Unit Business Management Model}

Based on the explanation above, that currently Allianz insurance has entered the 4.0 revolution, which has implemented a supporting system. The supporting system run by allianz insurance combines four important components, namely: insurance/financial literacy, network marketing, human technology, and digital technology. Financial literacy is an activity to educate the public, so that they have a complete understanding of the benefits of insurance. Network marketing is developing a network, to drive business growth. Human technology is used to produce reliable man power. Digital technology is a technological device that supports all transaction activities. This condition can be described as Figure 4 below.

\section{Figure 4. Allianz Insurance Supporting System}

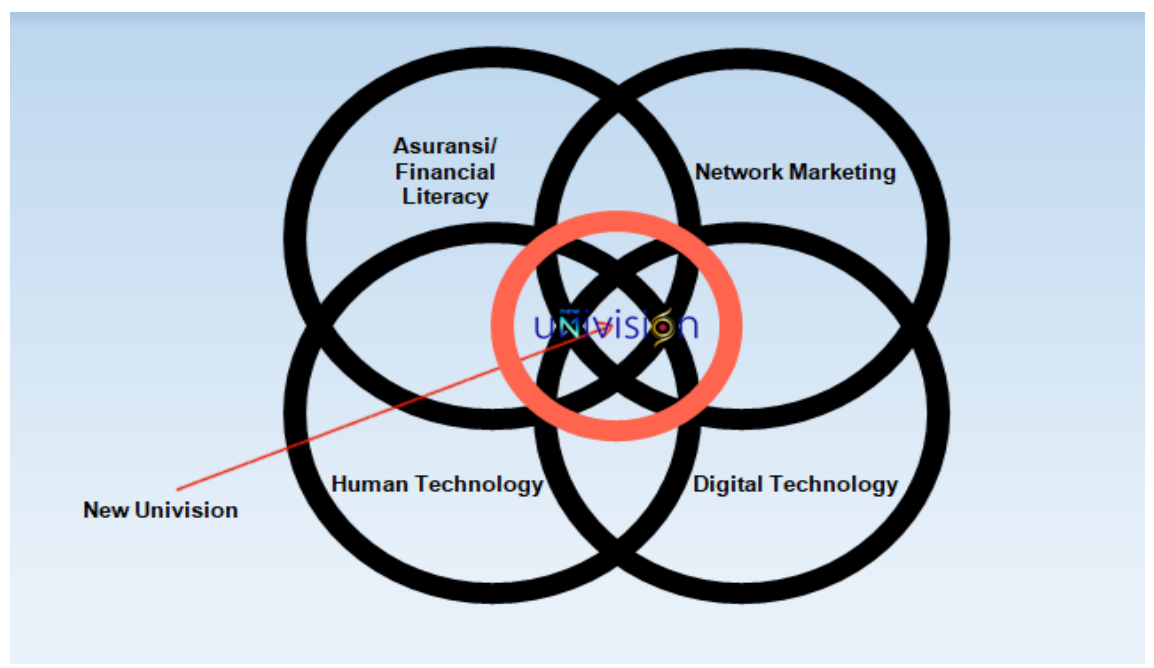

\section{Source: Primary data processed}

The application of digital technology is not only limited to premium payment transactions, but can include many transaction activities, which include, among others: the registration process and claim management. Thus, the technology owned by Allianz Syariah is able to adapt to the current trend. Moreover, with industrial changes and the increasingly dense routines that people live, it requires technology that is easy, fast, safe and comfortable in conducting various transactions, including insurance transactions. In addition, this digital technology was developed so that it can provide better services to customers, and customers are no longer dependent on agents.

To complement the above supporting systems, Univision Go was created which is a mechanism created by the Allianz insurance businessman in carrying out the insurance business. The tools used to make it easier for allianz insurance business players, so they can achieve the desired targets, include: 1) digital funneling, namely: making it easy for members to carry out prospecting activities through a digital funneling process in the form of article 
Sharia Insurance Company Business Management Model in The Digital 4.0 Era sharing, E-Books, Quotes, share picture, infographic and follow up automatically; 2) learning models, namely: a system that provides hundreds of learning training modules in the form of articles, audio, video, modules, and various business development tips; 3) gamification system, namely: a learning method that makes learning more fun. Below is a picture. 5, can describe the explanation.

\section{Figure 5. Application of the Allianz Insurance Industry Revolution 4.0}

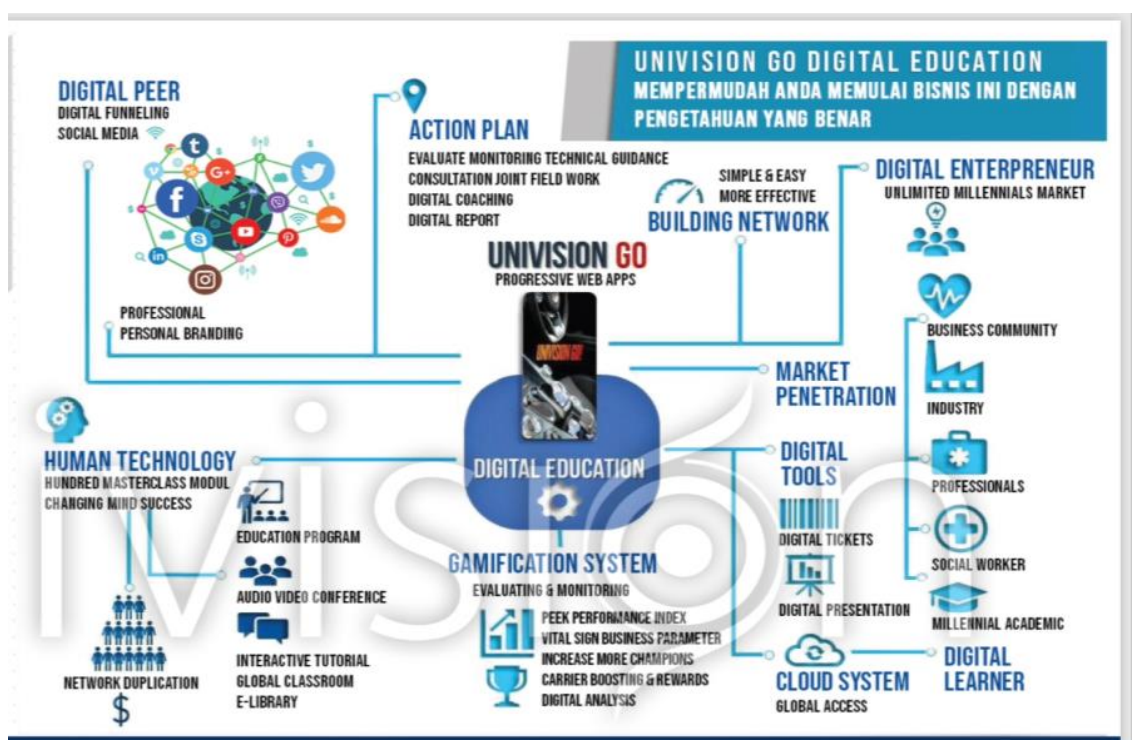

Source: Primary data processed

\section{CONCLUSION}

Based on the description above, it can be concluded that the journey of insurance business development has gone through the stages of the insurance industry revolution. Revolution phases that have been passed, namely: revolution 1.0, implementation of a branch sytem; revolution 2.0: adoption of the agency system; revolution 3.0: implementing a business system; and revolution 4.0: implementation of supporting systems.

The main components in running the Allianz sharia insurance business consist of insurance/financial literacy, network marketing, human technology, and digital technology. These components are an integral part of the Allianz Syariah supporting system, which is used as a driving force in driving the growth of the Allianz Syariah business. This mechanism was created through a group of sharia insurance business actors called Univision.

In carrying out the main components mentioned above, a device is needed that makes it easier for insurance business players. These devices, namely: digital funneling, learning models, gamification systems. If this tool can be applied and duplicated properly by Allianz insurance business actors, then they will be able to achieve the targets they want to achieve.

\section{REFERENCES}

Iqtishadia: Jurnal Ekonomi dan Perbankan Syariah 
Abdullah, Junaidi. "Akad-Akad Di Dalam Asuransi Syariah." TAWAZUN : Journal of Sharia Economic Law 1, no. 1 (2018): 11.

Agustin, Inneke Wahyu. "Perbandingan Pengembangan Asuransi Syariah Di Indonesia Dan Malaysia (Analisis Aliran Mazhab Sejarah Dan Law as a Tool of Social Engineering)." AlAhkam Jurnal Ilmu Syari'ah dan Hukum 5, no. 1 (2020): 37-57.

Ahmad Tanzeh. Metodologi Penelitian Praktis. Yogyakarta: Teras, 2011.

Bogdan, Robert C, Steven J. Taylor. Prosedur Penelitian. Dalam Moleong, Pendekatan Kualitatif. Jakarta: Rineka Cipta, 2012.

Effendi, Afif. "ASURANSI SYARIAH DI INDONESIA (Studi Tentang Peluang Ke Depan Industri Asuransi Syariah)." Wahana Akademika: Jurnal Studi Islam dan Sosial 3, no. 2 (2016): 71.

Handayani, Tati, and Muhammad Anwar Fathoni. "Persepsi Masyarakat Terhadap Asuransi Syariah." Conference on Islamic Management Accounting and Economics 2 (2019): 127132.

Hendrianto, and Riska Misdalepa. "STRATEGI MARKETING MENINGKATKAN NASABAH ASURANSI SYARIAH (STUDI KASUS DI ASURANSI SYARIAH AJB BUMIPUTERA1912 CURUP) Hendrianto,." Al-Qasd 1, no. 2 (2017): 127-142.

Herry Ramadhani. "PROSPEK DAN TANTANGAN PERKEMBANGAN ASURANSI SYARIAH DI INDONESIA Herry." AL-TIJARY Vol. 01, no. No. 01 (n.d.): 57-66.

Ichsan, Nurul. "Peluang Dan Tantangan Inovasi Produk Asuransi Umum Syariah." Jurnal Ekonomi Islam 7, no. 2 (2016): 131-156.

Iltiham, Muhammad Fahmul, and Dian Wahyuni. "STRATEGI AGEN ASURANSI SYARIAH DALAM MENINGKATKAN JUMLAH NASABAH (Studi Kasus Di PT. Asuransi Takaful Indonesia Malang)." Malia 7, no. 1 (2016): 1-26.

Miftakhul Jannah, Dinna, and Lucky Nugroho. "Strategi Meningkatkan Eksistensi Asuransi Syariah Di Indonesia." Jurnal Maneksi 8, no. 1 (2019): 169-176.

Moh. Nazir. Metode Penelitian. Bogor: Ghalia Indonesia, 2017.

Munawaroh, Sofiyatul, and Hasan Mukhibad. "Determinan Yang Mempengaruhi Financial Performance Pada Perusahaan Asuransi Umum Syariah Di Indonesia." IQTISHADIA: Jurnal Ekonomi \& Perbankan Syariah 6, no. 2 (2019): 155.

Rafidah, Rahma Lili Erfida Sholiha. "Pembayaran Premi Asuransi Melalui Aplikasi Mobile Agen Dalam Rangka Penguatan Bisnis Di Revolusi Industri 4.0 Di Jambi Indonesia." AlMasraf (Jurnal Lembaga Keuangan dan Perbankan) 5, no. 1 (2020): 11-20.

Soemitra, Laila Mardiyah Nainggolan; Andri. "The Contribution Income, Investment Results, 232 Iqtishadia: Jurnal Ekonomi dan Perbankan Syariah Vol.8 No.2 Desember 2021 

and Claim Expenses on Sharia Life Insurance Income." JEBIS : Jurnal Ekonomi dan Bisnis Islam 6, no. 2 (2020): 201-220.

Sugiyono. Metode Penelitian Kualitatif, Kuantitatif, Dan R\&D. Cet. Ke-27. Bandung: ALFABETA, 2018.

Toyyibah, Toyyibah, and Erie Hariyanto. "Implementasi Manajemen Resiko Pada Sistem Asuransi Jiwa Syariah Di Pt. Prudential Life Assurance Cabang Madura." IQTISHADIA: Jurnal Ekonomi \& Perbankan Syariah 2, no. 2 (2015): 146.

Witasari, Aryani, and Junaidi Abdullah. "Tabarru" Sebagai Akad Yang Melekat Pada Asuransi Syariah." BISNIS : Jurnal Bisnis dan Manajemen Islam 2, no. 1 (2014): 115.

Www.forbes.com.

"Lists

Global2000." Https://Www.Forbes.Com/Lists/Global2000/\#295563545ac0. 2021, Accessed May 28, 2021.

www.jiwasraya.co.id. "Adu-Inovasi-Produk-Di-Kancah-Pertarungan-Asuransi-Jiwa." Https://Www.Jiwasraya.Co.Id/?Q=id/Berita/Berita-Asuransi/Adu-Inovasi-Produk-DiKancah-Pertarungan-Asuransi-Jiwa, Accessed May 28, 2021.

www.ojk.go.id."Statistik-IKNB-Syariah-Periode-Maret-2021."

Https://Www.Ojk.Go.Id/Id/Kanal/Syariah/Data-Dan-Statistik/IknbSyariah/Pages/Statistik-IKNB-Syariah-Periode-Maret-2021.Aspx, Accessed Mei 27, 2021. 